\title{
BANQUETES DE REIS E DO REI EM ALGUMA PROSA E TEATRO MEDIEVOS
}

\author{
Maria do Amparo Tavares Maleval \\ (Universidade do Estado do Rio de Janeiro)
}

\section{RESUMO}

O presente estudo tem por objetivo observar como a comida é representada em algumas obras da prosa e do teatro medievos de forma a servir à finalidade de doutrinação cristã ou de propagação da magnanimidade dos reis. Tais representações serão, pois, observadas enquanto recursos retóricos, como técnicas de persuasão, tendo em vista que servem a propósitos de conversão religiosa ou de propaganda política.

PALAVRAS-CHAVE: alimentação, doutrinação, Retórica.

\section{ABSTRACT}

This study aims to observe how the food is represented in some works of medieval prose and theater in order to serve the purpose of Christian indoctrination or spread the magnanimity of kings. Such representations will therefore be seen as rhetorical devices, as persuasion techniques in order to serve the purposes of religious conversion or political propaganda.

KEYWORDS: Food, Indoctrination, Rhetoric. 
Muitos anos se passaram desde o lançamento de A arte de comer em Portugal na Idade Média, de Salvador Dias Arnault (1986). Foi com muito interesse que na ocasião o li, pois se trata de um elucidativo estudo sobre o tema, já que de modo bastante minucioso são descritos, com base em fontes primárias do medievo português, as cozinhas e utensílios, o serviço, o uso de comerem os homens em separado, os banquetes, as três refeições diárias dos abastados ${ }^{1}$ e os alimentos mais usados no período - como o pão, as carnes, os peixes, mariscos, legumes, frutas e doces. ${ }^{2}$ Refere-se inclusive às especiarias, principalmente a pimenta, cujo consumo já desde o século XII era indicado em documentos. Quanto ao vinho, demonstra que era habitualmente consumido por pobres e ricos, por vezes misturado com água, sendo severamente reprovados os abusos dos alcoólatras. ${ }^{3} \mathrm{~A}$ moderação era, pois, recomendada no comer e no beber, sendo veementemente condenado pelos tratadistas - como D. Duarte no Leal Conselheiro (1982) - o pecado da gula. E o jejum era praticado pelos que se dedicavam de forma mais empenhada à religião. ${ }^{4}$

O nosso estudo, sem desprezar algumas informações preciosas desse livro (e não só), pretende observar como a comida é representada em algumas obras da prosa e do teatro medievos de forma a servir à finalidade de doutrinação cristã ou de propagação da magnanimidade dos reis. Tais representações serão, pois, observadas enquanto recursos retóricos, como técnicas de persuasão, tendo em vista que servem a propósitos de conversão religiosa ou de propaganda política.

Aristóteles (s.d., p. 34) acentuou a importância capital das provas no processo argumentativo, separando inicialmente as provas não-técnicas, ou não-artísticas, das técnicas ou criadas no discurso. Aquelas diriam respeito a documentos e testemunhas. Estas, a meios persuasivos criados ou manipulados pelo orador. E seriam de três ordens: fundamentadas no ethos, isto é, no caráter moral do orador, que pela sua respeitabilidade já asseguraria credibilidade ao discurso e a subsequente persuasão dos receptores; fundamentada no logos, ou seja, no caráter racional do discurso; e no pathos, direcionado para o despertar das emoções no auditório, pois, como reconhecia o Sábio, “obtém-se a persuasão nos ouvintes quando o discurso os leva a sentir uma paixão, porque os juízos que proferimos variam consoante experimentamos aflição ou alegria, amizade ou ódio" (ARISTÓTELES, s.d., p. 35). Estas últimas servem, pois, à eloquência pelas sensações, empolgantes por excelência.

Teremos em vista esses recursos de persuasão no que concerne ao tema de que nos ocupamos - a comida - nas obras escolhidas para as nossas reflexões, as quais foram escritas entre os séculos XIII e XVI: a anônima novela de cavalaria A Demanda do Santo Graal, a Crónica de D. Pedro de Fernão Lopes, as Crónicas de D. João II escritas por Rui de Pina e Garcia de Resende, e o Auto da Alma de Gil Vicente. Embora as últimas já tenham sido elaboradas em um período francamente mercantilista, que com Massaud Moisés podemos chamar de Humanismo (MALEVAL, 1992), a 
mentalidade nelas veiculada é medieval, pois, como nos ensina Le Goff, a mentalidade custa muito mais a modificar-se que os fatores econômicos e sociais: "A mentalidade é aquilo que muda mais lentamente. História das mentalidades, história da lentidão na história” (LE GOFF, 1976, p. 72). Principalmente a religiosa, que será privilegiada em nosso enfoque, pois, como destaca Alphonse Dupront, "O fenômeno religioso pertence, do ponto de vista temporal, ao longo prazo. Mais ainda: as suas transformações, mesmo a sua evolução, são muito lentas, no que se refere aos hábitos adquiridos e à visão de mundo" (DUPRONT, 1976, p. 83).

\section{AS MARAVILHOSAS IGUARIAS DO GRAAL}

A Demanda do Santo Graal é incontestavelmente uma das mais preciosas construções do Ocidente medieval. Seu exemplar mais completo hoje existente é o manuscrito 2594 da Biblioteca Nacional de Viena, uma cópia datada do século XV de tradução portuguesa, feita entre os séculos XIII e XIV de original francês ducentista. Inserida "num ciclo vasto e tardio da literatura arturiana”, hoje conhecido como Post-Vulgata (NUNES, 1995, p. 7), apresenta uma evidente cristianização de lendas bretãs. Este fato se comprova inclusive na observação das referências ao comer feitas em momentos cruciais da narrativa, através de imagens de forte apelo sensorial que tornam mais eficaz a doutrinação religiosa objetivada. Disto trataremos a seguir.

Quando o Rei Artur reúne os seus cavaleiros da Távola Redonda em Camaalot na festa de Pentecostes - celebração cristã que comemora, 50 dias após a Páscoa, a descida do Espírito Santo sobre os Apóstolos com a presença de Galaaz, o puro dos puros e como tal determinado para o encontro do Vaso Sagrado, grande foi a "lidice e o prazer" que tiveram. Momento de felicidade incomparável, pois, após ouvirem um trovão "tam grande e tam espantoso" (DEMANDA, 1995, p. 35) e se verem em meio a uma imensa claridade, ficaram repletos da Graça do Espírito Santo. Emudecidos de espanto, "virom-se mui mais fremosos" diante do Graal, coberto por um pano de veludo branco, que flutuava sobre suas cabeças, dado que ninguém conseguiu ver quem o trazia. E, maravilhados, "siam calados e catavam-se ũũs aos outros" (DEMANDA, 1995, p. 35). Em sequência, "foi o paaço todo comprido de bõõ odor, como se todalas espécias do mundo i fossem" (DEMANDA, 1995, p. 35). E, o que nos interessa mais por agora, "per u passava, logo todalas mesas eram compridas de tal manjar qual em seu coraçom desejava cada ũũ. E depois que houve cada ũũ o que houve mester a seu prazer, saiu-se o Santo Graal do paaço que niũũ nom soube que fora dele nem por qual porta saira" (DEMANDA, 1995, p. 36).

A imagem é uma amostragem do êxtase místico, momento de felicidade completa, que impulsionaria definitivamente os cavaleiros à busca do Graal. Nesse momento de prazer imenso, todos os sentidos humanos se viram contemplados, na seguinte ordem: audição, através do espantoso 
trovão ouvido e da mudez subsequente às maravilhas presenciadas; visão, inundado que foi o local de uma inusitada claridade; tato, se considerarmos "catar" os companheiros não apenas como olhar ou procurar, mas "esforçar por tomar, por agarrar" (MACHADO, v. II, p. 95) a formosura de que todos foram cobertos, bem como os alimentos a que tiveram acesso; olfato, diante do inusitado bom odor que lhes foi proporcionado; e paladar, já que a cada um foi possibilitado comer as delícias mais apetecidas.

Que a comida inigualável, mais que os outros fatores, marcou tal maravilha, provam as palavras do rei Artur aos seus cavaleiros: "muito devíamos a seer ledos que Deus nos mostrou tam gram signal de amor que em tam boa festa como hoje, de Pinticoste, que nos deu a comer do seu santo celeiro" (DEMANDA, 1995, p. 36; grifo nosso). Não se refere ele às demais beatitudes, mas ao comer, que desta forma a todas se sobrepõe. Mesmo Galvam, o cavaleiro desleal, lhe faz coro ao afirmar que "nom há cavaleiro no paaço que nom houvesse de comer quanto pensou cada ũũ em seu coraçom" (DEMANDA, 1995, p. 36). No entanto, refuta este, a maravilha só se completaria com o reencontro e a visão completa do Graal: "de tanto fomos enganados que o nom vimos senam coberto" (DEMANDA, 1995, p. 36). E promete iniciar a demanda, no que foi seguido pelos demais cavaleiros, que enfatizam o comer: "disserom que já mais nom quedariam de andar ataa que vissem atal mesa e tam saborosos manjares e atam guisados como eram aqueles que eles aquel dia comerom" (DEMANDA, 1995, p. 37). Então, diante do desolado rei, abandonam o reino, que tanto lhe custara unificar e fortalecer, à sua sorte.

Mas apenas doze cavaleiros - o mesmo número dos apóstolos eleitos por Jesus Cristo - conseguem ver o Santo Graal, no Paaço Aventuroso do reino de Corberic. À frente deles, Galaaz, após ter, por ordem divina e através de objetos miraculosos, curado o Rei Pescador, Peleam, dono daquelas terras e paralítico de há muito, atribulado com chagas que nunca se cicatrizavam.

Galaaz, com Palamedes, Persival e Boorz, seus mais próximos companheiros em virtudes, seguidos pelos demais adentra a câmara onde se encontrava o Santo Vaso. E, ajoelhados, ficam tão felizes diante da visão do objeto sagrado "que bem lhis semelhou que nunca haviam de morrer" (DEMANDA, 1995, p. 436). Então lhes aparece um homem de branco e com o rosto tão sobrenaturalmente iluminado que seus olhos não podiam ser por eles vistos. E lhes oferece o manjar tão desejado, agora totalmente cristianizado: a hóstia, transubstanciação do corpo de Cristo, que deu primeiramente a Galaaz, por considerá-lo "mais leal e melhor ca outro cavaleiro", e depois a cada um dos demais.

Destacamos o fato de o narrador se dirigir ao leitor/ouvinte para descrever a maravilhosa sensação experimentada pelos que comungaram: "Mas bem sabede que nom havia i tal deles a que nom semelhasse ca lhi metiam na boca ũu homem vivo e nom houve i tal que cuidasse que era 
em terra mas em céus. Ende haveo que houverom tam gram lediça e tam grande prazer que mortal coraçom nom podia pensar" (DEMANDA, 1995, p. 437). É uma representação do êxtase místico muito mais dramática que a do banquete do qual inicialmente falamos, já que ao receberem a hóstia sentiam engolir o próprio Cristo que se fez homem.

A obra se apresenta, desse modo, sem dúvidas, como veículo de doutrinação cristã. Seu caráter retórico se evidencia não por provas ligadas à racionalidade, mas ao caráter moral dos personagens e sobretudo pelo recurso aos argumentos emocionais, patéticos.

Se nos reportarmos à instituição da Eucaristia na última ceia de Jesus com seus discípulos, na noite em que foi entregue para o sacrifício redentor, vemos que ele reparte o pão e lhes oferece dizendo: "Isto é o meu corpo que é dado por vós. Fazei isto em minha memória" (Lucas, 22, 7-20 in Bíblia, 1981, p. 1373). Aliás, a palavra "hóstia" procede do latim hostia, significando "a vítima sacrificada, particularmente Cristo no sacrifício eucarístico” (LAROUSSE, 1998, p. 3030). E o Catolicismo, como se lê em seu Catecismo (1999, p. 365), considera a Eucaristia "fonte e ápice de toda a vida cristã". "Os demais sacramentos, assim como todos os ministérios eclesiásticos e tarefas católicas, se ligam à sagrada Eucaristia e a ela se ordenam". E conclui: "Pois a santíssima Eucaristia contém todo o bem espiritual da Igreja, a saber, o próprio Cristo, nossa Páscoa” (CATECISMO, 1999, p. 365).

Portanto, muito mais que na Bíblia ou no Catecismo a imagem da comunhão na Demanda impressiona e, com isto, certamente melhor atingiria aos destinatários medievos da obra, que, diante da espantosa descrição da sensação experimentada - de um homem vivo ser engolido pelos cavaleiros - e do sentimento de prazer intenso por esta proporcionado, seriam mais facilmente convertidos.

Galaaz foi tornado rei de Corberic por imposição da população, após o rei Peleam haver sido curado e se tornado ermitão. E a sua morte desejada, venturosa, sem sofrimentos, acontece após ter recebido a hóstia de Josefes, filho de José de Arimatéia, que também vira e sentira as maravilhas do Graal, trancendendo os limites humanos na epifania da experiência mística, na completude da manifestação divina a que poucos tiveram acesso. Acentua o narrador que, pela santidade de uma vida nunca conspurcada pela luxúria, isto lhes foi facultado: a contemplação das "cousas espiritaes", "o que a língua mortal nom podiria dizer nem coraçom pensar" (DEMANDA, 1995, p. 456). E a alma de Galaaz ascende aos céus, conduzida por anjos.

Não se pode esquecer que o paladar se apresenta, para os homens comuns, como o mais importante dos sentidos, até por ser a comida indispensável à manutenção da vida. É através da hóstia, então, que o Deus cristão se faz também alimento, concretizando a espiritualidade. Mas sairemos por agora do plano do sagrado a fim de observarmos a comida nas mesas dos reis - já que nas dos pobres os registros são muito raros ou inexistentes -, tal qual se apresenta em algumas páginas das crônicas medievais. 


\section{A ESPANTOSA FARTURA NOS BANQUETES DOS REIS}

Comer em celebrações é obviamente prática usual em momentos e civilizações diversas. Em Portugal, ficaram célebres alguns banquetes oferecidos por reis, dentre os quais destacaremos os de D. Pedro I e D. João II, inseridos no recorte temporal que nos propusemos observar: o medievo, compreendido na longa duração das mentalidades.

As crônicas que deles tratam, enquanto obras historiográficas, aproximam-se do tipo de discurso que Aristóteles (s.d., p. 43) chamava de judicial, que tem por finalidade distinguir o justo e o injusto com base em provas não artísticas (documentos e testemunhas) do passado. Mas o judicial, frisa o Estagirita (ARISTÓTELES, s.d., p. 43), raramente vem despojado das técnicas de argumentação do discurso deliberativo ou político, que trata do útil e do prejudicial objetivando aconselhar para ações futuras, e do epidítico, que trata do belo e do feio através do louvor ou da censura. Assim, os cronistas não apenas buscaram documentar as histórias dos reis e demonstrar a sua justiça - virtude destacada pelo Sábio, ao lado da coragem, temperança, magnificência, magnanimidade, liberalidade, mansidão, prudência, sabedoria (ARISTÓTELES, s.d., p. 71) -, como também defender, aconselhar e exaltar, através da construção do discurso em que os fatos são mostrados, a excelência das suas atitudes, o seu bom governo, a sua magnanimidade, a qual "permite realizar grandes benefícios" (ARISTÓTELES, s.d., p. 71), etc.

O reinado de $\mathrm{D}$. Pedro é narrado em páginas magistrais, no século XV, pelo primeiro cronista-mor de Portugal, Fernão Lopes. Cobrindo o período de 1357 a 1367, "diziam as gentes que tais dez anos nunca houvera em Portugal como estes que reinara el-rei Dom Pedro" (LOPES, 1977, p. 168). Isto porque se dedicou sobretudo a fazer justiça, sem distinguir entre os humildes e os poderosos, "regendo bem seu reino" (LOPES, 1977, p. 43). Embora se excedendo ao justiçar barbaramente, fugindo da palavra empenhada ao rei seu pai, dois dos assassinos da sua amada Inês de Castro, "amava muito de fazer justiça com direito. E assim como quem faz correição andava pelo reino” (LOPES, 1977, p. 46). Então, a crônica recolhe várias provas da justiça praticada pelo rei, buscando desculpá-lo da bárbara vingança a que aludimos, bem como de outros excessos nessa prática; sobretudo através da comparação com Pedro, o Cruel, de Castela, a quem muitos capítulos da obra são dedicados, marcando-lhe a arbitrariedade dos crimes, perto dos quais as falhas do rei português se apequenavam.

D. Pedro de Portugal, o Justiceiro, além de reger bem o seu reino, aumentando-lhe os tesouros e assegurando-lhe a paz, despendia o seu tempo também "em monte e caça, de que era muito querençoso; e em danças e festas, segundo aquele tempo, em que tomava grande sabor que adur é agora para ser crido" (LOPES, 1977, p. 77).

Aproximando-se sempre dos seus súditos, inesquecíveis são os quadros que o demonstram, como quando vinha "em batéis de Almada 
para Lisboa e saíam-no a receber os cidadãos e todos os mesteres com danças e trebelhos, segundo então usavam. E ele saía dos batéis e metia-se na dança com eles e assim até o paço" (LOPES, 1977, p. 77); ou quando, atacado por insônia, acordou aos que dormiam no palácio e, ao som de trombas de prata, com a iluminação de tochas, "meteu-se pela vila em dança com os outros", despertando a todos, que "saíam às janelas a ver que festa era aquela ou porque se fazia. E andou el-rei assim grande parte da noite, e tornou-se ao paço em dança, e pediu vinho e fruta, e deitou-se a dormir" (LOPES, 1977, p. 168). Interessante observar o dado relativo à ceia então feita por D. Pedro: vinho e frutas, que, como bem demonstrou Salvador Dias Arnaut (1986, p. 31), seria habitual em refeições mais leves, exemplificando tal prática não apenas com D. Pedro, mas com D. Fernando, D. João I, etc.

Contudo o destaque maior, já que de comida tratamos, deve ser dado à grande festa realizada em Lisboa, na ocasião em que João Afonso Telo foi feito conde e armado cavaleiro: além de profusamente iluminada por círios a cerimônia, foi seguida de danças noite adentro. No dia seguinte, sob grandes tendas armadas próximas ao mosteiro da sagração, no Rossio, "havia grandes montes de pão cozido e assaz de tinas cheias de vinho e logo prestes porque bebessem" (LOPES, 1977, p. 78). Essa abundância de pão e vinho se fazia acompanhar pela de carne, de forma pantagruélica, dado que fora das tendas "estavam vacas inteiras em espetos a assar" (LOPES, 1977, p. 78)! Essas vacas inteiras eram facultadas como comida a todos os que ali se encontravam, dentre os quais homens do povo, já que "quantos comer queriam daquela vianda tinham-na muito prestes e a nenhum era vedada" (LOPES, 1977, p. 78).

Mas não se pense que D. Pedro, embora gostando muito de viandas (carnes), comesse mais que o comum: "era muito viandeiro, sem ser comedor mais que outro homem" - portanto, os excessos da gula não eram por ele cometidos. O que gostava mesmo era de comer em público e proporcionar comida em abundância aos presentes: "suas salas eram de praça em todos os lugares por onde andava, fartas de vianda em grande abastança" (LOPES, 1977, p. 45). E a sua magnanimidade, a outra grande virtude dos reis e fidalgos, fica dessa forma demonstrada.

Deixando o gago, popular e justiceiro - embora por vezes exagerado - rei D. Pedro, vamos, já para os fins da Idade Média, nos primórdios do mercantilismo, observar as atitudes no comer do grande rei D. João II e a abastança de seus banquetes.

D. João II, que reinou de 1481 a 1495, recebeu a alcunha de Príncipe Perfeito. Grande empreendedor e político, sob seu cetro foram tomadas todas as iniciativas para a expansão marítima que resultou na criação do vasto Império português, que abarcou possessões nos vários continentes, como se sabe. Dele, seu cunhado D. Manuel herdou o mais rico reino da cristandade, graças sobretudo ao monopólio do comércio de especiarias com a descoberta do caminho marítimo para as Índias. 
Considerado, "porventura, o maior dos Reis portugueses", na competente avaliação de Joaquim Veríssimo Serrão (1991, p. 24), tomou como brasão da sua casa, ao contrair matrimônio, conservando-o ao se tornar rei com os dizeres "Por tua ley e por tua grey" (PINA, 1950, p. 64), o significativo símbolo do Pelicano, ave capaz de alimentar os filhos com o próprio sangue. Conforme observamos em estudo anterior (MALEVAL, 1995, p. 142), pelo seu povo se doaria inteiramente - tal indica essa imagem, que na iconografia cristã representava o próprio Cristo, seu sacrifício redentor. Com isto, indicava ser divino o seu modelo, bem como o princípio da descendência divina do poder real, princípio este defendido por Luís XI da França.

Quanto à justiça, "foi Princepe mui justo, e mui amigo de justiça e nas exucuções dela mais riguroso, e severo, que piedoso" (PINA, 1950, p. 203). Portanto, tal severidade e rigor o aproximava de seu antepassado, Pedro, o Justiceiro. Longe de ser, no entanto, espontâneo e passional como este.

Também como D. Pedro, gostava de comer em público; mas com a diferença de que a comida não era comumente compartilhada por todos, constituindo mais um espetáculo ver o rei comendo por longo tempo, ao qual já seria uma honra presenciar. Enfim, era amante de cerimônias faustosas, e por meio delas firmava o seu poder e limitava o da nobreza.

Quando o seu filho e herdeiro D. Afonso se casou com a herdeira de Castela, em 1490, as festas que se realizaram em Évora foram mais que nunca pomposas. Até porque, com tal casamento, se tornava possível a União Ibérica sob a Coroa portuguesa, sonho maior do Príncipe Perfeito. Os dois banquetes organizados para a ocasião foram inigualáveis. E deles usufruíram não só os grandes fidalgos de Portugal e Castela, mas também o povo. Rui de Pina (1977) e Garcia de Resende (1991) narram, nas crônicas que sobre D. João II escreveram, o esplendor de tais festejos. Resende, mais que Rui de Pina, os descreve com detalhes, construindo um discurso amplificado que presentifica a grandiosidade dos mesmos. Daí o tomarmos por fonte das nossas observações a seguir.

Para as comemorações nupciais o rei mandou construir em Évora uma sala de madeira. Nela foram encenados momos - representações de caráter solene e espetacular, e cunho processional - e os banquetes, servidos, ao som de muitos instrumentos, diante de convidados vestidos com a maior ostentação, sob a influência da moda francesa. No primeiro deles, "ouve infinitas e diversas igoarias e manjares, e singular concerto, e abastança, e muitas e assina[la]das cerimônias” (RESENDE, 1991, p. 173). $\mathrm{A}$ descrição do serviço impressiona pela pompa a ele conferida: "era tamanha a cerimônia, que durava muito cada vez que iam à mesa". E sempre acompanhado pelo som de instrumentos potentes, pelo "estrondo das trombetas, atambores e charamelas, e sacabuxas", sendo que "isto se fazia cada vez que el Rei, a Rainha, o Príncipe, a Princesa bebiam e vinham as primeiras iguoarias à mesa" (RESENDE, 1991, p. 174). 
Mas o que é sobretudo espantoso, na descrição minuciosa feita por Resende, são os dois bois assados inteiros, puxando uma carreta dourada cheia de carneiros também assados inteiros e com os cornos dourados: "e vinha tudo posto num cadafalso tam baixo com rodetas per fundo dele, que não se viam, que os bois pareciam vivos, e que andavam" (RESENDE, 1991, p. 174). Para completar a surpreendente representação, "vinha um moço fidalgo com hũa aguilhada na mão, picando os bois, que parecia que andavam, e levavam a carreta” (RESENDE, 1991, p. 174). Após servidos a Princesa e demais fidalgos, foram dados ao povo: "com grande grita, e prazer, foram espedaçados, e levava cada um quanto podia” (RESENDE, 1991, p. 174).

Também impressionantes eram os pavões assados inteiros, servidos com os rabos, pescoços e cabeça emplumada. Fora isto, havia "muitas sortes de aves, e caças, manjares e frutas, tudo em muito grande abundância e muita perfeição" (RESENDE, 1991, p. 174). Após e durante tanta comilança, houve representações, "e depois da cea muitas danças, e outras muitas festas, que quase toda a noite duraram" (RESENDE, 1991, p. 175).

Dias depois, sem se interromperem os festejos, foi realizado o outro grande jantar, "de muitas mais invenções, abastança e gentileza [...] e muito melhor servido que o primeiro" (RESENDE, 1991, p. 175). Em seu término, houve "muitos e ricos momos, e mui singulares entremezes, cada vez com mais riqueza, gentileza e melhores invenções, que duraram até acerca da manhã” (RESENDE, 1991, p. 175-176).

Fora da sala de madeira, "toda a gente da Corte e da Cidade, [...] que era muita, todos comiam do que se tirava das mesas, que era em tanta abondança, que muito mais era o que sobejava, que o que se comia" (RESENDE, 1991, p. 176). Conclui o cronista que tal banquete foi realizado "em tanta abastança, e tanta perfeição, tanta honra, tanto estado, quanto no mundo podia ser" (RESENDE, 1991, p. 176). Atesta-se, dessa forma, a magnificência do Príncipe Perfeito.

E continuaram os festejos até o Natal, sendo que o casamento realizou-se em final de novembro de 1490. Mas poucos meses depois, em 11 de julho de 1491, o Príncipe herdeiro morreria tragicamente, de uma queda de cavalo. E o sonho de D. João II cairia por terra.

Em 1495, o próprio soberano morreria. Não sem antes, com a orientação do seu confessor, Frei João da Póvoa, ter dado provas de humildade e arrependimento dos seus atos, visto que chegou mesmo a assassinar um dos cunhados (o duque de Viseu) e levar outro ao cadafalso (o duque de Bragança) em sua luta pela centralização e manutenção do poder. Correu mesmo a fama de sua santidade, dado que o seu cadáver não se corrompeu sob a ação da cal, o que tem sido explicado pela suspeita de haver sido envenenado com arsênico ou por seu corpo haver sido embalsamado. O certo é que evitou uma guerra civil, deixando o trono em testamento ao seu cunhado D. Manuel, afastando dessa forma as pretensões que pudesse ter o seu filho bastardo, D. Jorge. 
A Rainha-Viúva, D. Leonor, irmã de D. Manuel, dedicou-se a obras de caridade, criando inclusive a Misericórdia de Lisboa, e ao incentivo de publicações religiosas, dentre as quais o tratado doutrinário Bosco Deleitoso, publicado em 1515, por ser "enclinada a toda virtude e bem-fazer, zelosa grandemente de sua salvaçam e de tôda alma cristaâ", como se lê na dedicatória desse livro (BOOSCO, 1950, p. 1). Foi também a principal mecenas do considerado criador do teatro português, Gil Vicente, cujos autos de devoção veiculam ensinamentos do franciscanismo, norteador da Rainha Velha, como era então chamada D. Leonor, que era membro da Ordem Terceira de São Francisco.

Aliás, se atentarmos para as palavras da Mofina Mendes, no auto vicentino que tal personagem passou a intitular - "todo o humano deleite/ como meu pote d'azeite/ há de dar consigo em terra" (VICENTE, 2002, p. 126) -, estas se afiguram como uma profunda reflexão acerca das tragédias humanas, como a que cercou a família do Príncipe Perfeito: no momento do maior resplendor, atestado inclusive pelo fausto das festas do casamento do príncipe herdeiro, vê-se diante do phatos mais doloroso, com a sua morte tão precoce e inesperada. É como se a vida imitasse a arte, dado que no teatro o phatos se apresenta como o momento mais altamente trágico da peça, provocando no espectador sentimentos de temor ou compaixão (ARISTÓTELES, s.d., p. 313) e conduzindo à catarse.

\section{O BANQUETE REDENTOR DA SANTA ESTALAJADEIRA}

Temos demonstrado em estudos vários (MALEVAL, 2013a, 2013b) a doutrinação espiritual perpetrada pela retórica de Gil Vicente em suas "moralidades". Com relação ao tema de que estamos tratando - a comida -, salta à vista a importância do Auto da Alma (VICENTE, 2002, p. 189-213) para as presentes reflexões.

Considerada uma das mais importantes obras do dramaturgo e a sua mais gótica realização, o auto, segundo a indicação da rubrica inicial, foi escrito sob encomenda da "muito devota rainha dona Lionor e representado ao muito poderoso e nobre rei dom Emanuel seu irmão, por seu mandado, na cidade de Lisboa, nos paços da Ribeira, em a noite de Endoenças, Era do Senhor de 1508” (VICENTE, 2002, p. 189). Portanto, foi encenado para a família real em uma quinta-feira da Paixão. Aliás, é um dos poucos autos vicentinos destinados à Semana Santa, já que em sua maioria o foram para o Natal.

Apresenta a ideia, defendida por Santo Agostinho - de quem significativamente são as falas primeira e última do auto -, da existência humana como uma peregrinação rumo à "pátria verdadeira" (VICENTE, 2002, p. 191), a "eternal morada de Deos" (VICENTE, 2002, p. 189). E a didascália, indicando de forma clara o argumento do auto, fala da necessidade de estalagem espiritual para descanso e alimentação dos caminheiros, da mesma forma que na vida material acontece, sendo tal estalajadeira a "madre santa Igreja": 
Assi como foi cousa muito necessária haver nos caminhos estalagens pera repouso e refeição dos cansados caminhantes, assi foi cousa conveniente que nesta caminhante vida houvesse ũa estalajadeira pera refeição e descanso das almas que vão caminhantes pera a eternal morada de Deos. Esta estalajadeira das almas é a madre santa Igreja, a mesa é o altar, os manjares as insígnias da paixão (VICENTE, 2002, p. 189).

Esclarece, pois, que nessa estalagem "a mesa é o altar, os manjares as insígnias da paixão” (VICENTE, 2002, p. 126). A tal banquete a Alma, peregrinando entre a orientação do Anjo Custódio e as tentações do Diabo, só terá acesso após se encontrar verdadeiramente arrependida de haver sucumbido às tentações demoníacas. Essas tentações são dirigidas à sua vaidade através de falas imbuídas de lisonja e outros hábeis recursos persuasivos, bem como do oferecimento de presentes - como vestimentas, calçados, joias e propriedades materialmente valiosos, mas que a tornam pesada, opaca, cansada e vagarosa em sua caminhada existencial.

Conforme observamos em estudos anteriores (MALEVAL, 2013b), o Diabo serve-se de argumentos lógicos para persuadir ou convencer a Alma dos sofismas que lhe apresenta: utiliza-se do discurso bíblico, subvertendo-lhe o sentido, para incitá-la a não ter pressa em se salvar, pois há tempo para semear e plantar e colher; sendo o homem o senhor da criação, pode usufruir de todos os bens da terra; e o livre arbítrio lhe garante o direito de fazer escolhas. Assim, subverte o ensinamento bíblico contido no Eclesiates (III, 1-8) na sua argumentação, reiterada, com relação ao tempo: "Há i tempo de folgar/ e idade de crecer/ e outra idade/ de mandar e triunfar/ [...]/ Ainda é cedo pera a morte/ tempo há de arrepender e ir ao céu" (VICENTE, 2002, p. 197-198).

Também o senso comum é evocado para aconselhar a escolha dos valores materiais: "todos fazem assi" (VICENTE, 2002, p. 194). E a Alma termina por ceder à opinião comum: "Faço o que vejo fazer/ polo mundo" (VICENTE, 2002, p. 196) -, o que nos remete a Platão, de quem muitos ensinamentos foram assimilados pelo Cristianismo, no que Santo Agostinho teve um papel fundamental. Dentre outras lições, Platão afirmava que, se a alma humana consegue evoluir, "chega a conhecer as essências, esse conhecimento das verdades puras a mergulha na maior das felicidades" (PLATÃO, s.d., p. 226). Mas as que não o conseguem, "na impossibilidade de se elevarem até a contemplação do Ser Absoluto, caem e a sua queda as condena à simples Opinião" (PLATÃO, s.d., p. 227). A explicação dessa atração para o "céu da Verdade" é que "somente aí poderiam elas encontrar o alimento capaz de nutri-las e de desenvolver-lhes as asas, aquele que conduz a alma para longe das baixas paixões" (PLATÃO, s.d., p. 227).

Voltando a Gil Vicente, vemos que, no discurso da Igreja-estalajadeira e seus doutores, os argumentos não são lógicos, situam-se muito mais no domínio do patético, destinados a comover o auditório. E tudo é apresentado através da alegoria, recurso importantíssimo num contexto como 
o medievo, em que as abstrações tinham de ser concretizadas para serem entendidas pela maioria da população, analfabeta, inclusive os nobres.

É comovente o mea culpa enunciado pela Alma, desde o reconhecimento de que "pecou/ culpas mortais" (VICENTE, 2002, p. 202) reconhecendo-se então "mais morta que a morte", "carregada de vaidades peçonhentas" (VICENTE, 2002, p. 202) -, até o da necessidade de ser ajudada pela "Igreja madre" devido à sua fraqueza diante das tentações: "Consolai minha fraqueza/ com sagrada iguaria/ que pereço", "porque o que eu merecia/ bem conheço" (VICENTE, 2002, p. 203). Diante disto, a Igreja personificada - uma alegoria, pois - a recebe, junto com seus "pilares": Santo Agostinho, São Jerônimo, Santo Ambrósio e São Tomás, chamados para servir à Alma os melhores dos manjares (VICENTE, 2002, p. 204).

A Alma, "assentada à mesa e o Anjo junto com ela em pé, é, pois, servida pelos doutores da Igreja, que trazem "quatro bacios de cozinha cobertos cantando Vexila Regis prodeunt" (VICENTE, 2002, p. 205). Após invocação, em oração "feita pera Santo Agostinho", sobre a encarnação e paixão de Jesus Cristo e os sofrimentos de sua Mãe, referendada por Santo Ambrósio e São Jerônimo, a Alma lava e enxuga as mãos. A água, diz Santo Agostinho, são as "lágrimas da culpa vossa" (VICENTE, 2002, p. 209); e a toalha, a mesma com que Verônica enxugara o rosto do Redentor em sua via crucis.

Após a adoração desse objeto sagrado, retirado dos bacios por Santo Agostinho, feita "de joelhos cantando Salve sancta facies" (VICENTE, 2002, p. 210), a madre Igreja manda vir a primeira iguaria, apresentada por São Jerônimo, concretizando-a quanto ao preparo e ao paladar: foi "guisada sem alegria/ em triste dia/ a crueldade cozinheira/ e matadora./ Gostá-la-eis com salsa e sal/ de choros de muita dor/ porque os costados/ do messias divinal/ santo sem mal/ foram pólo vosso amor/ açoutados" (VICENTE, 2002, p. 210-211). Tal iguaria são os açoites que, após retirados dos bacios, "todos de joelhos adoram cantando Ave flagellum" (VICENTE, 2002, p. 211).

Também a São Jerônimo cabe apresentar a segunda iguaria, dizendo "que haveis de mastigar/ em contemplar/ a dor que o senhor do mundo/ padecia/ pera vos remediar./ Foi um tromento improviso/ que aos miolos lhe chegou/ e consentiu/ por remediar o siso/ que a vosso siso faltou/ e pera ganhardes paraíso/ a sofriu" (VICENTE, 2002, p. 211). Trata-se da coroa de espinhos, "que é retirada dos bacios e adorada de joelhos, com o cântico Ave corona espinearum" (VICENTE, 2002, p. 211).

E São Jerônimo traz a terceira iguaria, manjar "guisado / em três lugares de dor/ a qual maior/ com a lenha do madeiro/ mais prezado./ Come-se com grã tristeza/ porque a virgem gloriosa/ o viu guisar/ viu cravar com grã crueza/ a sua riqueza/ e sua perla preciosa/ viu furar" (VICENTE, 2002, p. 212). São os cravos que, expostos, "todos de joelhos os adoram cantando Dulce lignum dulcis clavus" (VICENTE, 2002, p. 212). 
Finda a adoração dessas iguarias, a Alma, orientada pelo Anjo, despe-se das indumentárias e joias que o inimigo lhe dera, sob o júbilo de Santo Agostinho, que diz: "Dais o seu cujo é/ o da terra à terra/ agora ireis despejada/ pola estrada/ porque vencestes com fé/ forte guerra” (VICENTE, 2002, p. 212). E o quarto e último manjar é trazido por São Jerônimo: um crucifixo, que "adoram cantando Domine Jesu Christe" (VICENTE, 2002, p. 213).

Das palavras que a seguir a Alma enuncia pode-se depreender que os recursos patéticos da retórica da comoção atingem o seu objetivo: exaltar a pequenez humana diante da grandiosidade do divino: "Com que forças com que spirito/ te darei tristes louvores/ que sou nada/ vendo-te Deos infinito/ tam aflito/ padecendo tu as dores/ e eu culpada?". A interrogação retórica desempenha importante papel nesse processo de comoção, que certamente atinge ao público de forma contundente, fazendo-o participante do espetáculo - ele que já fora certamente atingido através do presencialismo das imagens, direcionadas não só ao paladar, mas ao outros sentidos como a visão e a audição, esta principalmente através dos cânticos que acompanham cada adoração. E continua: "Como estás tam quebrantando/ filho de Deos imortal/ quem te matou?/ senhor per cujo mandado/ és justiçado/ sendo Deos universal/ que nos criou?" (VICENTE, 2002, p. 213).

E a convite de Santo Agostinho vão todos adorar o santo sepulcro, cantando Te deum laudamus, encerrando-se dessa forma o auto.

\section{CONSIDERAÇÕES FINAIS}

Mais uma vez observamos no teatro de Gil Vicente um vasto uso de argumentos diversos, adequados a cada situação, personagem e finalidade do discurso. As provas, como vimos acima destacadas por Aristóteles (s.d., p. 34) como elementos fundamentais na argumentação persuasiva, no Auto vicentino se apresentam artisticamente construídas. E se fundamentam ora no ethos, isto é, no caráter moral do orador, que garante por si a credibilidade do discurso (nas falas do Anjo Custódio, da Igreja e seus doutores, principalmente de Santo Agostinho, a quem cabe o primeiro e o último discurso - portanto o exórdio e a peroração); ora no logos, ou seja, no caráter racional do discurso (presente no discurso do Diabo, que, como vimos, se utiliza de argumentos lógicos, inclusive da autoridade da Bíblia cujos valores são subvertidos, para seduzir a Alma, transformando o falso em verdadeiro como faziam os sofistas); ora no pathos, com vistas a despertar as sensações mais fortes no auditório (como vimos no caso do banquete em que são servidas as iguarias da Paixão de Cristo, acentuando-lhe a imensa dor sofrida pela salvação da humanidade). Estas últimas servem, pois, à eloquência mais empolgante, à doutrinação mais eficaz, tornando sublime o estilo.

Aliás, Santo Agostinho, em A doutrina cristã (2002), fornece segura orientação para a arte da prédica, fundamentando-se inclusive em 
Cícero - por sua vez, leitor de Aristóteles -, citando o mestre romano da oratória em várias passagens da obra. Inclusive ao falar da necessidade de variar os estilos no discurso, recomendando ao pregador o estilo simples para ensinar, o temperado para censurar ou louvar e o sublime para converter: "Mas quando for preciso determinar à ação os ouvintes que deveriam agir, mas que resistem, ele empregará, então, para expor as grandes verdades, o estilo sublime e os acentos próprios a comover os corações" (AGOSTINHO, 2002, p. 245).

Voltando a Gil Vicente, com o Auto da Alma intentou levar o espectador ou leitor a desconfiar por completo das falácias mundanas, seus falsos valores, e a aceitar as lições da Patrística, cuja veracidade é confirmada através do banquete sagrado que permite o surgimento da compaixão e da alegria maior.

Também em A Demanda do Santo Graal vimos a doutrinação religiosa ser perpetrada através de forte apelo sensorial, sendo que as delícias do Vaso Sagrado, impulsionadoras da sua busca, terminam por se concretizarem na hóstia, o sacramento maior da Igreja. No ato da comunhão, o mistério da transubstanciação é materializado da forma mais veemente na sensação, experimentada pelos cavaleiros, de engolirem o corpo vivo do Cristo.

Se no banquete do Rei os manjares se apresentam como provas do seu amoroso gesto redentor e das delícias celestiais, nos banquetes dos reis o são da magnanimidade e magnificência destes. Assim, D. Pedro e D. João II têm tais virtudes demonstradas da forma mais impressionante, através da fartura de alimentos e da espantosa apresentação dos animais de grande porte assados e servidos inteiros em seus festejos. Dessa forma, as provas não-artísticas, ou seja, os documentos e testemunhas em que os cronistas se fundamentaram, manipulados por estes, terminam por construir singulares painéis, que colocam diante de nossos olhos as comemorações de outrora.

\section{REFERÊNCIAS BIBLIOGRÁFICAS}

ARISTÓTELES. Arte retórica e arte poética. Trad. de Antonio Pinto de Carvalho. Rio de Janeiro: Ed. Ouro, s.d..

AGOSTINHO (Sto.) A doutrina cristã. Trad. Ir. Nair de Assis Oliveira, csa. São Paulo: Paulus, 2002.

ARNAUT, Salvador Dias. A arte de comer em Portugal na Idade Média. Lisboa: Imprensa Nacional - Casa da Moeda, 1986.

BÍBLIA DE JERUSALÉM (A). S. Paulo: Edições Paulinas, [1981]. 
BOOSCO Deleitoso. Edição do texto de 1515 preparada por Augusto Magne, com introd., notas e glossário. Rio de Janeiro: MEC - Instituto Nacional do Livro, 1950.

CATECISMO da Igreja Católica. Ed. revisada de acordo com o texto em latim (1997). São Paulo: Edições Loyola, 1999. Reimpressão: maio de 2006.

DEMANDA do Santo Graal (A). Edição de Irene Freire Nunes. Lisboa: Imprensa Nacional - Casa da Moeda, 1995.

DUARTE, D. Leal Conselheiro. Lisboa: Imprensa Nacional - Casa da Moeda, 1982.

DUPRONT, Alphonse. Antropologia religiosa. In LE GOFF Jacques; NORA Pierre (Orgs.). História: novas abordagens. Trad. de Henrique Mesquita, revisão de Dirceu Lindoso e Theo Santiago. Rio de Janeiro: Francisco Alves, 1976, p. 83-105.

FREITAS, Irene Nunes. Introdução. DEMANDA do Santo Graal (A). Edição de Irene Freire Nunes. Lisboa: Imprensa Nacional - Casa da Moeda, 1995, p. 7-14

LAROUSSE Cultural. Grande Enciclopédia. São Paulo: Nova Cultural, 1998.

LE GOFF, Jacques. As mentalidades. In ; NORA, Pierre (Orgs.). História: novos objetos. Trad. de Terezinha Marinho, revisão de Gadiel Perruci. Rio de Janeiro: Francisco Alves, 1976, p. 68-83.

MALEVAL, Maria do Amparo Tavares. Humanismo. In MOISÉS, Massaud (Dir.). A literatura portuguesa em perspectiva. Trovadorismo. Humanismo. São Paulo: Editora Atlas, 1992, p. 97-190.

A construção da imagem do Príncipe Perfeito: D. João II. In . Rastros de Eva no imaginário ibérico (séculos XII a XVI). Santiago de Compostela: Laiovento, 1995, p. 140-154.

. Revisitando o "Boosco Deleitoso" na companhia de Gil Vicente. Colóquio Letras. Lisboa, n. 182, p. 9-20, jan. 2013a.

Da retórica do franciscanismo nas moralidades de Gil Vicente. Conferência apresentada no XXIV Congresso Internacional da ABRAPLIP, realizado em Campo Grande de 20 a 25/10/2013b. Atas no prelo.

PLATÃO. Fedro. In: Diálogos. Rio de Janeiro, Ediouro, s.d..

PINA, Rui de. Crónica Del rei D. João II. Ed. com prefácio e notas de Alberto Martins de Carvalho. Coimbra: Atlântida, 1950. 
RESENDE, Garcia de. Crónica de D. João II e Miscelânea. Reimpressão facsimilada da nova edição conforme a de 1798. Prefácio de Joaquim Veríssimo Serrão. Lisboa: Imprensa Nacional - Casa da Moeda, 1991.

SERRÃO, Joaquim Veríssimo. Apresentação. In MENDONÇA, Manuela. D. João II. Um percurso humano e político nas origens da modernidade em Portugal. Lisboa: Editorial Estampa, 1991.

VICENTE, Gil. As obras de Gil Vicente. Direcção científica de José Camões. Vol. I. Lisboa, IN-CM, 2002.

Recebido para publicação em 05/10/2013

Aprovado em 08/01/2014

\section{NOTAS}

1 Nas casas abastadas havia pela manhã o (pequeno) almoço, mais tarde o jantar (que corresponderia hoje ao nosso almoço) e a ceia.

2 Não eram utilizados o chá e o café. No mais, pelo visto, os alimentos não se diferiam muito dos que hoje consumimos, à exceção das carnes de caças.

3 Alguns eram abstêmios, como a rainha Santa Isabel, esposa de D. Dinis, e o rei D. João II, que se viram obrigados a tomar vinho muito tardiamente, por indicação médica.

4 Inclusive havia os que, como a Rainha Santa, Nun'Álvares, o infante D. Henrique e o Infante Santo, D. Fernando, jejuavam a pão e água. Ou os que, como a mãe destes últimos, D. Filipa de Lencastre, o faziam com moderação. Inclusive o marido desta, D. João I, embora gostasse de comer bem, recomendava, para o bom exercício da montaria, que fossem evitados "os mui grandes vícios do comer, e do beber sem razão" (apud ARNAUT, 1986, p. 101).

5 Modernizamos a ortografia desta e demais citações das crônicas de Pina e Resende, respeitando as diferenças fonológicas. Ex: "igoaria”, hoje "iguaria”. 